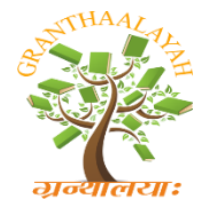

INTERNATIONAL JOURNAL OF RESEARCH GRANTHAALAYAH A knowledge Repository

Management

\title{
A COMPARITIVE STUDY ON SERVICE QUALITY PERCEPTION AND PREFERENCE OF CUSTOMERS ABOUT PUBLIC AND PRIVATE SECTOR BANKS IN TIRUNELVELI DISTRICT
}

\author{
G. Bright Jowerts ${ }^{* 1}$, Dr. C. Eugine Franco ${ }^{2}$ \\ ${ }^{* 1}$ Assistant Professor in Commerce, St. Xavier's College (Autonomous), Palayamkottai, India \\ ${ }^{2}$ Associate Professor in Commerce \& Dean of students, St. Xavier's College (Autonomous), \\ Palayamkottai, India
}

DOI: https://doi.org/10.29121/granthaalayah.v5.11(SE).2017.1919

\begin{abstract}
Service Quality of the banks referred as an obligation of all banks to fulfill the objectives and needs of the customers. The present need of banks is to have good relationship with customers by providing quality services to retain the existing and generate or acquire new customers. Thus, this study attempts to study the service quality in the banking sector in the present scenario. The scope of this study is to identify the service quality of public and private banks in Tirunelveli district. This research is based on primary data and secondary data. This study only focuses on the dimensions of service quality i.e. reliability, assurance, tangibility, empathy and responsiveness. The primary data was collected from 300 customers of banks located in Tirunelveli district. The analysis was carried out with the responses of the customers of the public sector banks and private sector banks by adopting stratified random sampling through questionnaire and presented in the form of tabulation. This study brought to light the fact that the customers were very much satisfied on the service quality of the banks in the region but at the same time they expect a lot more from the banks in the present scenario of technological developments in banks.
\end{abstract}

Keywords: Service Quality; Perception; Preference; Banking; Public \& Private Sector.

Cite This Article: G. Bright Jowerts, and Dr. C. Eugine Franco. (2017). “A COMPARITIVE STUDY ON SERVICE QUALITY PERCEPTION AND PREFERENCE OF CUSTOMERS ABOUT PUBLIC AND PRIVATE SECTOR BANKS IN TIRUNELVELI DISTRICT." International Journal of Research - Granthaalayah, 5(1)SE, 32-42. https://doi.org/10.29121/granthaalayah.v5.i1(SE).2017.1919.

\section{Introduction}

Across all service industries, service quality remains a critical issue in maintaining and propagating business in the competitive marketplace. To survive in a highly competitive service 
environment, it is apparent that service industries need to provide customer with high quality services. Customer today demands quality and from their point of view, quality is nothing but an integral and expected part of service that is service quality. In banking, quality means not just meeting but exceeding customer expectations. For this reason, service quality is viewed as an important aspect in the banking industry. Further, it is evident that over the years, bank customers' perception of service quality has been changed tremendously. Today, quality includes a commitment towards continuous improvement and service relationships with customers. Also, the need for technology based services, new and improved product services and e-services are also viewed as important aspects of banking service quality that supports improved and superior quality services provided to customers. Hence, these are the areas where banks have to focus upon in order to satisfy their customers.

\section{Statement of the Problem}

Service Quality of the banks referred as an obligation of all banks to fulfill the objectives and needs of the customers. In General it is perused that, service quality in private sector banks is good compared to public sector banks. The various issues the banks are not able to provide immediate response to customers, service time duration is more, long queue to deposit the money, waiting for long time, staff behavior is not good, especially public sector banks are not providing multitude services like payment of bills, payment of tax, Banc assurance etc. and problem relating to banking service such as bank statements, error in the statements are not provided immediate response to customers. Parking facility in banks is very poor compared to private sector banks. The biggest challenge today for the bank is to establish customers intimacy without which all other efforts towards operationed excellence are meaningless. The present need of banks is to have good relationship with customers by providing quality services to retain the existing and generate or acquire new customers. Thus, this study attempts to study the service quality in the banking sector in the present scenario.

\section{Scope of the Study}

The scope of this research is to identify the service quality of public and private banks in Tirunelveli district. This research is based on primary data and secondary data. This study only focuses on the dimensions of service quality i.e. reliability, assurance, tangibility, empathy and responsiveness. It aims to understand the skill of the banks in the area of service quality that are performing well and shows those areas which require improvement. The study was done taking two types of banks such as public and private banks in Tirunelveli district into consideration. The survey was restricted to the bank customers in Tirunelveli district only.

\section{Objectives of the Study}

The study has the following objectives.

- To examine the service quality gap determinants on the quality of services of banking sector.

- To compare the service quality provided by public and private sector banks in Tirunelveli District. 


\section{Methodology of the Study}

The study was carried out with both primary and secondary data. The primary data was collected from 300 customers of banks located in Tirunelveli district. The analysis was carried out with the responses of the customers of the public sector banks and private sector banks by adopting stratified random sampling through questionnaire and presented in the form of tabulation.

\section{Sampling Design}

For the purpose of primary data collection, ten banks were selected. Five banks from public sector banks namely State Bank of India (SBI), Indian Overseas Bank (IOB), Canara Bank (CB), Indian Bank (INB) and State of Bank of Travancore (SBT) and five banks from private sector namely Housing Development Finance Corporation Bank (HDFC), Industrial Credit and Investment Corporation of India Bank (ICICI), AXIS Bank, Tamilnadu Mercantile Bank (TMB) and Karur Vysya Bank (KVB) in Tirunelveli district. Out of these banks, 30 customers were selected each from public sector banks and private sector banks in Tirunelveli district. Thus, 300 customers were selected on the basis of stratified random sampling method for the present study.

\section{Limitations of the Study}

- All the answers given by the respondents have been assumed true.

- Customers have provided necessary information for some questions from their memory and experience whose accuracy is not satisfactory.

- In this research, only 300 respondents are considered to suggest the five dimensions of service quality of banking in Tirunelveli district. Large sample of respondents may produce better results.

- The service quality is a vast subject consisting of a number of dimensions. The most common five service quality dimensions namely, Tangibility, Reliability, Responsiveness, Assurance, and Empathy only were analyzed in the present study.

\section{Analysis and Interpretation}

Table 1: Gender wise classification of Respondents

\begin{tabular}{|l|l|l|l|}
\hline \multirow{2}{*}{ Type of Banks } & \multicolumn{2}{|l|}{ Gender } & \multirow{2}{*}{ Total } \\
\cline { 2 - 3 } & Male & Female & \\
\hline Public banks & $92(61.3)$ & $58(38.7)$ & $150(100)$ \\
\hline Private banks & $133(88.7)$ & $17(11.3)$ & $150(100)$ \\
\hline Total & $\mathbf{2 2 5 ( 7 5 )}$ & $\mathbf{7 5 ( 2 5 )}$ & $\mathbf{3 0 0}(\mathbf{1 0 0})$ \\
\hline
\end{tabular}

Source: Primary Data (Parentheses indicates percentage)

Bank wise analysis reveals that among the customers of public banks, a majority of 92 respondents (61.3 per cent) are male and in private banks, also a majority of 133 respondents (88.7 per cent) are male. The simple reason for the majority of the male respondents having account in public and private banks in the study area is that male respondents independently open accounts in banks. But the female respondents are not financially liberated and they are 
dependent upon their father or husband for opening of accounts with banks. Hence, majority of the male respondents have account in public and private banks than female.

Table 2: Age wise classification of Respondents

\begin{tabular}{|c|c|c|c|c|c|c|}
\hline \multirow[t]{2}{*}{ Type of Banks } & \multicolumn{5}{|c|}{ Age (Number of Respondents) } & \multirow[t]{2}{*}{ Total } \\
\hline & $\begin{array}{l}\text { Below } 20 \\
\text { years }\end{array}$ & $\begin{array}{l}21-40 \\
\text { years }\end{array}$ & $\begin{array}{l}41-50 \\
\text { years }\end{array}$ & $\begin{array}{l}51-60 \\
\text { years }\end{array}$ & $\begin{array}{l}\text { Above } \\
60 \text { years }\end{array}$ & \\
\hline Public banks & $51(34)$ & $56(37.3)$ & $15(10)$ & $19(12.7)$ & $9(6)$ & $150(100)$ \\
\hline Private banks & $22(14.7)$ & $78(52)$ & $28(18.7)$ & $16(10.7)$ & $6(4)$ & $150(100)$ \\
\hline Total & $73(24.3)$ & $134(44.7)$ & $43(14.3)$ & 35(11.7) & 15(5) & 300(100) \\
\hline
\end{tabular}

Source: Primary Data (Parentheses indicates percentage)

Bank wise analysis reveals that among the customers of public banks, a majority of 56 respondents ( 37.3 per cent) are in the age group of 21 to 40 years and in private banks, a majority of 78 respondents (52 per cent) are in the age group of 21 to 40 years. Majority of the young aged respondents have account in public and private banks in the study area. The reason is that young aged respondents are more eager to save money in the banks and also they prefer to take money through ATM. But the old aged respondents are eager to invest in other investment avenues other than banks. Hence, majority of the young aged respondents maintain account in public and private banks than old aged respondents.

Table 3: Motivational factors to choose the Banks

\begin{tabular}{|l|l|l|l|l|l|l|}
\hline \multirow{2}{*}{ Type of Banks } & \multicolumn{5}{|l|}{ Factors (Number of Respondents) } & \multirow{2}{*}{ Total } \\
\cline { 2 - 6 } & $\begin{array}{l}\text { Fast } \\
\text { services }\end{array}$ & $\begin{array}{l}\text { Easy } \\
\text { access }\end{array}$ & $\begin{array}{l}\text { Quick } \\
\text { transactions }\end{array}$ & $\begin{array}{l}\text { Good } \\
\text { approach }\end{array}$ & $\begin{array}{l}\text { Low } \\
\text { interest } \\
\text { rate on } \\
\text { loan }\end{array}$ & \\
\hline Public banks & $28(18.7)$ & $91(60.7)$ & $27(18)$ & $4(2.7)$ & - & $150(100)$ \\
\hline Private banks & $21(14)$ & $92(61.3)$ & $25(16.7)$ & $5(3.3)$ & $7(4.7)$ & $150(100)$ \\
\hline Total & $\mathbf{4 9}(\mathbf{1 6 . 3})$ & $\mathbf{1 8 3}(\mathbf{6 1})$ & $\mathbf{5 2 ( 1 7 . 3 )}$ & $\mathbf{9 ( 3 )}$ & $\mathbf{7 ( 2 . 3 )}$ & $\mathbf{3 0 0 ( 1 0 0 )}$ \\
\hline
\end{tabular}

Source: Primary Data (Parentheses indicates percentage)

Bank wise analysis reveals that among the customers of public banks, 91 respondents (60.7 per cent) are motivated by easy access and in private banks, 92 respondents (61.3 per cent) are also motivated by easy access. Among various factors that influence the customers to open up an account with a bank, may be private or public, easy access to the bank gets prime importance. In a fast moving world customers want to get the job done immediately. It is evident from the study that the factor easy access to the bank has motivated the customers to open up accounts with banks in Tirunelveli district. 
Table 4: Type of Account

\begin{tabular}{|l|l|l|l|l|l|}
\hline Type of Banks & \multicolumn{3}{|l|}{ Type of account (Number of Respondents) } & Total \\
\cline { 2 - 5 } & $\begin{array}{l}\text { Savings } \\
\text { account }\end{array}$ & $\begin{array}{l}\text { Current } \\
\text { account }\end{array}$ & $\begin{array}{l}\text { Fixed } \\
\text { deposit } \\
\text { account }\end{array}$ & $\begin{array}{l}\text { Recurring } \\
\text { deposit } \\
\text { account }\end{array}$ & \\
\hline Public banks & $127(84.7)$ & $13(8.7)$ & $8(5.3)$ & $2(1.3)$ & $150(100)$ \\
\hline Private banks & $94(62.7)$ & $42(28)$ & $13(8.7)$ & $1(0.7)$ & $150(100)$ \\
\hline Total & $\mathbf{2 2 1}(\mathbf{7 3 . 7})$ & $\mathbf{5 5}(\mathbf{1 8 . 3})$ & $\mathbf{2 1 ( 7 )}$ & $\mathbf{3 ( 1 )}$ & $\mathbf{3 0 0}(\mathbf{1 0 0})$ \\
\hline
\end{tabular}

Source: Primary Data (Parentheses indicates percentage)

Bank wise analysis reveals that among the customers of public banks, a majority of 127 respondents (84.7 per cent) have savings account and in private banks, a majority of 94 respondents (62.7 per cent) have savings account. Generally customers prefer to maintain savings accounts with private or public banks. They really find it more convenient to have savings account. Current accounts are being maintained by business people only.

Table 5: Period of Maintaining the Account

\begin{tabular}{|l|l|l|l|l|}
\hline \multirow{2}{*}{ Type of banks } & \multicolumn{2}{|l|}{ Period of maintaining the account } & \multirow{2}{*}{ Total } \\
\cline { 2 - 4 } & Below 3 years & $\mathbf{3}$ to 6 years & Above 6 years & \\
\hline Public banks & $61(40.7)$ & $39(26)$ & $50(33.3)$ & $150(100)$ \\
\hline Private banks & $40(26.7)$ & $48(32)$ & $62(41.3)$ & $150(100)$ \\
\hline Total & $\mathbf{1 0 1}(\mathbf{3 3 . 7})$ & $\mathbf{8 7}(\mathbf{2 9})$ & $\mathbf{1 1 2}(\mathbf{3 7 . 3})$ & $\mathbf{3 0 0}(\mathbf{1 0 0})$ \\
\hline
\end{tabular}

Source: Primary Data (Parentheses indicates percentage)

Bank wise analysis reveals that among the customers of public banks, a majority of 61 respondents ( 40.7 per cent) have account for below 3 years and in private banks, a majority of 62 respondents ( 41.3 per cent) of the respondents have account for 6 years and above. Majority of the respondents are having their account for over 6 years. Thus, the half of the respondents is customers of the bank and they need to be provided utmost care to retain them as customers for longer period.

\section{Service Quality Gap in Banking Sector}

In order to find out the service quality of banking sector, that is of the public and private banks in Tirunelveli district, the data have been collected from the customers using 33 variables. The service quality gap is calculated by

\section{Service quality gap $=$ Expectation - Perception}

\section{Service quality Gap in Public Sector Banks in Tirunelveli District}

The following table shows the service quality gap in public sector banks in Tirunelveli district. 
Table 6: Service quality Gap in Public Sector Banks in Tirunelveli District

\begin{tabular}{|c|c|c|c|c|}
\hline $\begin{array}{l}\text { Sl. } \\
\text { No }\end{array}$ & Statements & $\begin{array}{l}\text { Expectation } \\
\text { Mean }\end{array}$ & $\begin{array}{l}\text { Perception } \\
\text { Mean }\end{array}$ & $\begin{array}{l}\text { Service } \\
\text { quality gap }\end{array}$ \\
\hline & Tangibility & 4.46 & 2.66 & 1.80 \\
\hline 1 & Bank location & 4.03 & 3.08 & 0.95 \\
\hline 2 & Parking services & 4.42 & 2.62 & 1.80 \\
\hline 3 & Seating facility & 4.54 & 3.76 & 0.78 \\
\hline 4 & Ventilation & 4.97 & 2.45 & 2.52 \\
\hline 5 & Bank equipments & 4.32 & 2.14 & 2.18 \\
\hline 6 & Bank slips (forms) & 4.23 & 2.55 & 1.68 \\
\hline \multirow[t]{2}{*}{7} & Location of ATM Centre & 4.77 & 2.05 & 2.72 \\
\hline & Assurance & 4.69 & 2.53 & 2.16 \\
\hline 8 & Safety of transaction & 4.71 & 2.46 & 2.25 \\
\hline 9 & Savings interest rate & 4.68 & 2.86 & 1.82 \\
\hline 10 & Loan interest rate & 4.70 & 2.26 & 2.44 \\
\hline 11 & Working hours & 4.70 & 2.58 & 2.12 \\
\hline \multirow[t]{2}{*}{12} & Safety of deposits & 4.70 & 2.48 & 2.22 \\
\hline & Reliability & 4.67 & 2.44 & 2.23 \\
\hline 13 & Speed transaction on services & 4.65 & 2.25 & 2.40 \\
\hline 14 & ATM services & 4.68 & 2.76 & 1.92 \\
\hline 15 & Credit card services & 4.68 & 2.29 & 2.39 \\
\hline 16 & Transaction accuracy & 4.64 & 2.69 & 1.95 \\
\hline 17 & Loan facility & 4.66 & 2.13 & 2.53 \\
\hline 18 & Service charges & 4.69 & 2.31 & 2.38 \\
\hline 19 & Mortgage facility & 4.64 & 2.53 & 2.11 \\
\hline \multirow[t]{2}{*}{20} & Employee reliability & 4.70 & 2.53 & 2.17 \\
\hline & Responsiveness & 4.64 & 2.36 & 2.28 \\
\hline 21 & Providing information & 4.67 & 2.67 & 2.00 \\
\hline 22 & Solving the problem & 4.68 & 2.46 & 2.22 \\
\hline 23 & Relationship & 4.66 & 2.43 & 2.23 \\
\hline 24 & Immediate responses & 4.64 & 2.14 & 2.50 \\
\hline 25 & Employees knowledge & 4.63 & 2.32 & 2.31 \\
\hline 26 & Services promptness & 4.62 & 2.08 & 2.54 \\
\hline \multirow[t]{2}{*}{27} & Multitude services & 4.62 & 2.43 & 2.19 \\
\hline & Empathy & 4.63 & 2.46 & 2.17 \\
\hline 28 & Employees courtesy & 4.62 & 2.69 & 1.93 \\
\hline 29 & Staff behavior & 4.64 & 2.44 & 2.20 \\
\hline 30 & Individual attention & 4.65 & 2.44 & 2.21 \\
\hline 31 & $\begin{array}{l}\text { Understanding the need of } \\
\text { customers }\end{array}$ & 4.64 & 2.35 & 2.29 \\
\hline 32 & Sincerity in problem solving & 4.65 & 2.58 & 2.07 \\
\hline 33 & Pro-activeness & 4.61 & 2.52 & 2.09 \\
\hline
\end{tabular}

Source: Primary Data 
It is clear from the table 6 that the mean scores of expectations are high and range from 4.03 for (item 1: bank location) to 4.97 for (item 4: ventilation). Among the five dimensions, the highest expectation is related to the assurance dimensions (dimension's mean score $=4.69$ ) and the lowest expectation is related to the tangibility dimension (dimension's mean score $=4.46$ ). The mean score of the perceptions ranged from 2.14 for (item 5: Bank equipment's) to 3.76 for (item 3: seating facility). Among the five dimensions of quality, the highest perception related to the tangibility dimension (dimension's mean score $=2.66$ ) and the lowest perception related to the responsiveness dimension (dimension's mean score $=2.36$ ).

The gap score for each item and dimension was computed by subtracting the perception score from the expectation score. Table 6 further shows that the highest gap of the quality relates to the responsiveness dimension (gap mean score $=2.28$ ), and there is a considerable gap between the customers' expectations and perceptions. The lowest gap of the quality relates to the tangibility dimension (gap mean score $=1.80$ ).

\section{Service quality Gap in Private Sector Banks in Tirunelveli District}

The following table shows the service quality gap in private sector banks in Tirunelveli district.

Table 7: Service quality Gap in Private Sector Banks in Tirunelveli District

\begin{tabular}{|l|l|l|l|l|}
\hline $\begin{array}{l}\text { Sl. } \\
\text { No }\end{array}$ & Statements & $\begin{array}{l}\text { Expectation } \\
\text { Mean }\end{array}$ & $\begin{array}{l}\text { Perception } \\
\text { Mean }\end{array}$ & $\begin{array}{l}\text { Service } \\
\text { quality gap }\end{array}$ \\
\hline & Tangibility & $\mathbf{4 . 4 9}$ & $\mathbf{3 . 4 8}$ & $\mathbf{1 . 0 1}$ \\
\hline 1 & Bank location & 3.57 & 3.17 & 0.40 \\
\hline 2 & Parking services & 4.44 & 3.05 & 1.39 \\
\hline 3 & Seating facility & 4.68 & 3.38 & 1.30 \\
\hline 4 & Ventilation & 4.68 & 4.52 & 0.16 \\
\hline 5 & Bank equipments & 4.65 & 3.80 & 0.85 \\
\hline 6 & Bank slips (forms) & 4.71 & 2.18 & 2.53 \\
\hline 7 & Location of ATM Centre & 4.71 & 3.01 & 1.70 \\
\hline & Assurance & $\mathbf{4 . 4 8}$ & $\mathbf{3 . 1 1}$ & $\mathbf{1 . 3 7}$ \\
\hline 8 & Safety of transaction & 4.67 & 2.68 & 1.99 \\
\hline 9 & Savings interest rate & 4.73 & 3.43 & 1.30 \\
\hline 10 & Loan interest rate & 4.72 & 3.03 & 1.69 \\
\hline 11 & Working hours & 4.71 & 3.57 & 1.14 \\
\hline 12 & Safety of deposits & 3.57 & 2.83 & 0.74 \\
\hline & Reliability & $\mathbf{4 . 6 9}$ & $\mathbf{3 . 0 6}$ & $\mathbf{1 . 6 3}$ \\
\hline 13 & Speed transaction on services & 4.72 & 2.61 & 2.11 \\
\hline 14 & ATM services & 4.66 & 3.82 & 0.84 \\
\hline 15 & Credit card services & 4.69 & 2.58 & 2.11 \\
\hline 16 & Transaction accuracy & 4.69 & 4.06 & 0.63 \\
\hline 17 & Loan facility & 4.70 & 2.42 & 2.28 \\
\hline 18 & Service charges & 4.71 & 2.44 & 2.27 \\
\hline 19 & Mortgage facility & 4.70 & 3.44 & 1.26 \\
\hline 20 & Employee reliability & 4.72 & 3.12 & 1.60 \\
\hline & & & \\
\hline
\end{tabular}




\begin{tabular}{|l|l|l|l|l|}
\hline & Responsiveness & $\mathbf{4 . 6 6}$ & $\mathbf{3 . 2 9}$ & $\mathbf{1 . 3 7}$ \\
\hline 21 & Providing information & 4.72 & 3.32 & 1.40 \\
\hline 22 & Solving the problem & 4.74 & 2.68 & 2.06 \\
\hline 23 & Relationship & 4.62 & 2.68 & 1.94 \\
\hline 24 & Immediate responses & 4.72 & 3.02 & 1.70 \\
\hline 25 & Employees knowledge & 4.62 & 3.80 & 0.82 \\
\hline 26 & Services promptness & 4.59 & 3.92 & 0.67 \\
\hline 27 & Multitude services & 4.62 & 3.61 & 1.01 \\
\hline & Empathy & $\mathbf{4 . 6 7}$ & $\mathbf{3 . 5 3}$ & $\mathbf{1 . 1 4}$ \\
\hline 28 & Employees courtesy & 4.67 & 3.52 & 1.15 \\
\hline 29 & Staff behavior & 4.65 & 3.52 & 1.13 \\
\hline 30 & Individual attention & 4.68 & 3.64 & 1.04 \\
\hline 31 & $\begin{array}{l}\text { Understanding the need of } \\
\text { customers }\end{array}$ & 4.65 & 3.69 & 0.96 \\
\hline 32 & Sincerity in problem solving & 4.71 & 3.68 & 1.03 \\
\hline 33 & Pro-activeness & 4.66 & 3.44 & 1.22 \\
\hline
\end{tabular}

Source: Primary Data

It is clear from the table 7 that the mean scores of expectations are high and range from 3.57 for (item 1: bank location) to 4.74 for (item 22: solving the problem). Among the five dimensions, the highest expectation is related to the reliability dimensions (dimension's mean score $=4.69$ ) and the lowest expectation is related to the assurance dimension (dimension's mean score = 4.48). The mean score of the perceptions ranged from 2.18 for (item 6: Bank slips (forms) to 4.52 for (item 4: ventilation). Among the five dimensions of quality, the highest perception related to the empathy dimension (dimension's mean score $=3.53$ ) and the lowest perception related to the reliability dimension (dimension's mean score $=3.06$ ).

The gap score for each item and dimension was computed by subtracting the perception score from the expectation score. Table 7 further shows that the highest gap of the quality relates to the reliability dimension (gap mean score $=1.63$ ), and there is a considerable gap between the customers' expectations and perceptions. The lowest gap of the quality relates to the tangibility dimension ( gap mean score $=1.01$ ).

\section{Service quality Gap in public and private sector banks in Tirunelveli District}

The following table shows the service quality gap in public and private sector banks in Tirunelveli district.

Table 8: Service quality Gap in public and private sector banks in Tirunelveli District

\begin{tabular}{|l|l|l|l|l|}
\hline $\begin{array}{l}\text { Sl. } \\
\text { No }\end{array}$ & Statements & $\begin{array}{l}\text { Expectation } \\
\text { Mean }\end{array}$ & $\begin{array}{l}\text { Perception } \\
\text { Mean }\end{array}$ & $\begin{array}{l}\text { Service } \\
\text { quality gap }\end{array}$ \\
\hline & Tangibility & $\mathbf{4 . 5 1}$ & $\mathbf{3 . 0 1}$ & $\mathbf{1 . 5 0}$ \\
\hline 1 & Bank location & 4.41 & 3.40 & 1.01 \\
\hline 2 & Parking services & 3.99 & 2.90 & 1.09 \\
\hline 3 & Seating facility & 4.79 & 4.10 & 0.69 \\
\hline
\end{tabular}




\begin{tabular}{|l|l|l|l|l|}
\hline 4 & Ventilation & 4.67 & 3.06 & 1.61 \\
\hline 5 & Bank equipments & 4.00 & 2.83 & 1.17 \\
\hline 6 & Bank slips (forms) & 4.94 & 2.68 & 2.26 \\
\hline 7 & Location of ATM Centre & 4.74 & 2.11 & 2.63 \\
\hline & Assurance & $\mathbf{4 . 7 1}$ & $\mathbf{2 . 8 5}$ & $\mathbf{1 . 8 6}$ \\
\hline 8 & Safety of transaction & 4.71 & 2.73 & 1.98 \\
\hline 9 & Savings interest rate & 4.68 & 3.14 & 1.54 \\
\hline 10 & Loan interest rate & 4.71 & 2.65 & 2.06 \\
\hline 11 & Working hours & 4.72 & 3.07 & 1.65 \\
\hline 12 & Safety of deposits & 4.71 & 2.65 & 2.06 \\
\hline & Reliability & $\mathbf{4 . 6 8}$ & $\mathbf{2 . 7 5}$ & $\mathbf{1 . 9 3}$ \\
\hline 13 & Speed transaction on services & 4.69 & 2.43 & 2.26 \\
\hline 14 & ATM services & 4.65 & 3.26 & 1.39 \\
\hline 15 & Credit card services & 4.68 & 2.43 & 2.25 \\
\hline 16 & Transaction accuracy & 4.68 & 3.41 & 1.27 \\
\hline 17 & Loan facility & 4.69 & 2.36 & 2.33 \\
\hline 18 & Service charges & 4.68 & 2.28 & 2.40 \\
\hline 19 & Mortgage facility & 4.67 & 2.98 & 1.69 \\
\hline 20 & Employee reliability & 4.71 & 2.83 & 1.88 \\
\hline & Responsiveness & $\mathbf{4 . 6 5}$ & $\mathbf{2 . 8 3}$ & $\mathbf{1 . 8 2}$ \\
\hline 21 & Providing information & 4.69 & 3.00 & 1.69 \\
\hline 22 & Solving the problem & 4.71 & 2.57 & 2.14 \\
\hline 23 & Relationship & 4.64 & 2.55 & 2.09 \\
\hline 24 & Immediate responses & 4.68 & 2.58 & 2.10 \\
\hline 25 & Employes knowledge & 4.63 & 3.06 & 1.57 \\
\hline 26 & Services promptness & 4.60 & 3.00 & 1.60 \\
\hline 27 & Multitude services & 4.62 & 3.02 & 1.60 \\
\hline & Empathy & $\mathbf{4 . 6 5}$ & $\mathbf{2 . 9 9}$ & $\mathbf{1 . 6 6}$ \\
\hline 28 & Employees courtesy & 4.65 & 3.10 & 1.55 \\
\hline 29 & Staff behavior & 4.64 & 2.98 & 1.66 \\
\hline 30 & Individual attention & 4.67 & 3.04 & 1.63 \\
\hline 31 & Understanding the need of & 4.64 & 3.02 & \\
& customers & & 3.13 & 1.62 \\
\hline 32 & Sincerity in problem solving & 4.68 & 2.55 \\
\hline 33 & Pro-activeness & 4.64 & 1.66 \\
\hline & & & \\
\hline & & & & \\
\hline & & & & \\
\hline & & & \\
\hline
\end{tabular}

Source: Primary Data

It is clear from the table 8 that the mean scores of expectations are high and range from 3.99 for (item 2: parking services) to 4.79 for (item 3: seating facility). Among the five dimensions, the highest expectation is related to the assurance dimensions (dimension's mean score $=4.71$ ) and the lowest expectation is related to the tangibility dimension (dimension's mean score $=4.51$ ). The mean score of the perceptions ranged from 2.11 for (item 7: Location of ATM Centre) to 4.10 for (item 3: seating facility). Among the five dimensions of quality, the highest perception is related to the tangibility dimension (dimension's mean score $=3.01$ ) and the lowest perception is related to the reliability dimension (dimension's mean score $=2.75$ ). 
The gap score for each item and dimension was computed by subtracting the perception score from the expectation score. Table 8 shows further that the highest gap of the quality relates to the reliability dimension (gap mean score $=1.93$ ), and there is a considerable gap between the customers' expectations and perceptions. The lowest gap of the quality relates to the tangibility dimension (gap mean score $=1.50$ ).

\section{Suggestions to the Banks}

- The customer's perception of reliability dimension of service quality is lower in public sector banks. So the public sector banks may take steps to improve their sincerity in solving the problems of customers and keeping their promises.

- Banks must train all the employees in the areas of customer care, customer approach, body language, customer communication, customer need assessment and compliant management. This will help to pave the way for maintaining cordial relationship and improve the quality of services.

- The customer's perception of assurance dimension of service quality is lower in private sector banks. Hence, it is suggested that private sector banks may take steps to improve their trustworthiness and safety feelings in the minds of customers.

- Although there is no much difference in the customers perception of the customer contact programmes in both the banking sectors, the public sector banks may pay more attention to the customer's awareness programmes about new products and services, the periodical customer meets and the telephone recalls to remind customers.

- Bank should maintain good relationship with customers by providing necessary and needed services to the customers.

\section{Suggestions to the Customers}

- To get effective quality of services from the bank, customers should provide adequate time to the bank to do the work rather than disturbing and waiting in long queues and crowding before the counter.

- A customer has to learn about the banking formalities with the help of co-customers or with specific bank employee rather than disturbing employees involved in other activities.

- Customers should be aware of the modern developments in the banking activities, to facilitate the banks to provide quality services.

- To get quality banking services a customer has to utilize the available technological services in their bank rather than traditional way of approach.

- The evaluation of service quality during definite periods in order to identify new demand/ needs of the customers must be done periodically \& permanently.

\section{Conclusion}

This study brought to light the fact that the customers were very much satisfied on the service quality of the banks in the region but at the same time they expect a lot more from the banks in the present scenario of technological developments in banks. Hence, this study will pave way to 
further research to explore this mechanism in depth to provide quality banking services to facilitate the customers, the society and the economy as a whole.

\section{References}

[1] Borcherding, T. E., Pommerehne, W. W., Schneider, F., \& Schneider, F. (1982). Comparing the efficiency of private and public production: The evidence from five countries (pp. 127-156). Institute for Empirical Research in Economics University of Zurich.

[2] Golden, S. A. R. (2015). Regional Imbalance affecting quality of e-banking services with special reference to Tuticorin District-An Analysis. International Journal of Research, 2(3), 788-798.

[3] Golden, S. A. R., \& Regi, S. B. (2015). Satisfaction of Customers towards User Friendly Technological Services offered by Public and Private Sector banks at Palayamkottai, Tirunelveli District. International Journal of Research, 2(3), 775-787.

[4] Ismaila. Bootwala, Anjali Gokhru "A Study on Customers' Perception on Services Provided by Banks in the City of Ahmedabad", Pacific Business Review International, Volume.5, Issue.5, November 2012, pp.109-121.

[5] Mohsin Zafar, Sana Zafar, Aasia Asif, Ahmed Imran Hunjra, H. Mushtaq Ahmad "Service Quality, Customer Satisfaction and Loyalty: An Empirical Analysis of Banking Sector in Pakistan”, Information Management and Business Review, Vol. 4, No. 3, Apr 2012, pp. 159-167.

[6] Rajiv Sindwani and Manisha Goel, "Developments in Electronic Banking Service Quality", International Journal of Research in IT \& Management, Volume.2, Issue.5, May 2012, pp.37-43.

[7] Regi, S. B., \& Golden, S. A. R. (2014). A Study On Attitude Of Employee Towards Working Environment With Special Reference To RR Pvt Ltd. Review Of Research, 2 (2), 1, 5.

[8] Regi, S. B., \& Golden, S. A. R. (2014). Customer Preference Towards Innovative Banking Practices Available In State Bank Of India At Palayamkottai. Sankhya International Journal Of Management And Technology, 3 (11 (A)), 31, 33.

[9] Regi, S. B., \& Golden, S. A. R. (2014). Customer Preference Towards E-Channels Provided By State Of Bank Of India.

[10] Regi, S. B., Golden, S. A. R., \& Franco, C. E. (2014). ROLE OF COMMERCIAL BANK IN THE GROWTH OF MICRO AND SMALL ENTERPRISES. Golden Research Thoughts, 3 (7), $1,5$.

[11] Sathish, G. A STUDY ON LOAN PORTFOLIO MANAGEMENT OF URBAN COOPERATIVE BANKS IN TAMIL NADU.

[12] Vibhorjain, Sonia Gupta and Smrita Jain "Customer Perception on Service Quality in Banking Sector: With Special Reference to Indian Private Banks in Moradabad Region", International Journal of Research in Finance \& Marketing, Volume 2, Issue 2,February 2012, pp.597-610. 